\title{
Gharat: an environment friendly livelihood source for the natives of western Himalaya, India
}

\author{
Anupam Bhatt $^{1} \cdot$ Dipika Rana $^{1} \cdot$ Brij Lal $^{1}$ \\ Received: 1 April 2019 / Accepted: 20 April 2021 / Published online: 29 April 2021 \\ (c) The Author(s), under exclusive licence to Springer Nature B.V. 2021
}

\begin{abstract}
The native people of the Himalayan region use an indigenously designed watermill locally called as 'Gharat'. The 'Gharat' is made from the natural resources that are easily available in the area and operates through the water force coming from glaciers, perennial streams and rivulets. Thus, it is an environment friendly source of livelihood for the 'Gharatis' (the owner of Gharat). In the present communication, an effort was made to document the status of Gharats in the high-altitude Himalayan regions of Pangi and Tissa of district Chamba. Field surveys were conducted in a total of twenty remote villages of Pangi and Tissa regions (ten in each site). Information was collected on pre-designed semi-structured questionnaires from local people that primarily consisted of Gharatis, elderly informants and the inhabitants living in the vicinity of Gharats. All possible reasons responsible for the increase and reduction in the number of Gharats in the study areas were also documented by interviewing the informants. The study revealed that in the Pangi region number of Gharats have increased and are in good condition whereas there is a drastic decline in the number of Gharats in Tissa. The informants in Pangi gave maximum responses favouring motivational factors while in Tissa maximum responses were obtained for demotivational factors. Based on these responses, we prioritized the corrective measures for improving the efficiency of Gharats and restoration of this age-old indigenous and environment friendly technology. This will surely enhance livelihood security of the inhabitants besides optimum utilization of the natural resources in the Himalayan region.
\end{abstract}

Keywords Environment $\cdot$ Gharat $\cdot$ Himalaya $\cdot$ Indigenous $\cdot$ Livelihood $\cdot$ Sustainability

\section{Introduction}

Human sustainability lies in following laws of nature that are governed by mass and energy balance (Pereira, 2009). It is important that natural resources are used in a sustainable manner with balanced interaction of humans with technology, economic growth, environment and resources. The use of renewable natural sources can help

Brij Lal

brijihbt@yahoo.com

1 High Altitude Biology Division, CSIR-Institute of Himalayan Bioresource Technology (IHBT),

Palampur, Himachal Pradesh 176061, India 
combat the growing environmental problems in a long way (Nautiyal et al., 2011). Among the varied renewable resources like photovoltaic, solar thermal, tidal and wind energy, the hydropower stands out for its feasibility due to which its potential is harnessed around the world (Pérez-Sánchez et al., 2017). The Gharat (watermill) is one such indigenous technology that operates through the energy derived from flowing water coming from glaciers, perennial streams and rivulets and is used for the production of flour, lumber, textile or metal shaping.

The usage of rotary hand mills (quern) by primitive man for crushing and grinding food materials can be considered as an emergence of watermill. The oldest hand mills date back to the Palaeolithic period that were used to grind the tuberous roots and their further expansion occurred during the Neolithic period when human beings adopted a sedentary lifestyle over the nomadic and initiated the agricultural activities (Sánchez-Jiménez \& González, 2018). As Wheat cultivation came in existence in the Middle East between 10 and 8th millennia BC (Moritz, 1958), each family employed its own hand rotary mills (two stones) to grind grains. As the demand for flour increased with rising human population, man started to explore the ways to harness energy resources like water to operate large rotary stones for grinding (Boomgaard, 2008). The first reference of a mill driven by water was given by a Greek writer Antipater of Thessalonica in his writing in 85 BC (Rojas-Sola et al., 2006). The ancient water mills emerged simultaneously in two forms, the 'Greek Mill' with the horizontal waterwheel and the 'Roman Mill' with a vertical waterwheel. Until the mid of the twentieth century, some watermills continued to function while others got mechanized that ultimately led to the disappearance of the large number of classic horizontal watermills (Rojas-Sola et al., 2006). In the past, water mills were known to perform different functions like in Greece these were called as 'Norse Mill' and were used to grind grains, while in Syria these were called as 'Noriahs' and were used for running mills that processed cotton into cloth.

It is evident that the Himalayan region is a hub of diverse natural resources and its inhabitants exhibit a high diversity of cultures, traditions, resource use and stewardship practices with significant ecosystem-human interdependencies due to inaccessibility and heterogeneity of mountain systems (Bhatt et al., 2018; Everard et al., 2020; Huddleston et al., 2003). Despite blessed with the rich natural resources, the region is inhabited by around 175 million people who are still living below the poverty line (FAO, 2005; Sharma et al., 2010). This is mainly due to difficult terrains, environmental hazards, poor communication, transportations and low level of scientific and technological interventions in the mountain areas (Körner et al., 2005; Lal et al., 2019; Rao, 1997). The natives of high mountain areas have developed several indigenous technologies using locally available natural resources and their traditional wisdom. Some of these include Charkha (spinning wheel), Takali (spindle) made of wood or metal, Khaddi (wooden weaving machine) and Gharat (Panchakki/ watermill) (Lal et al., 2019; Rana et al., 2020). Water is one of the very useful natural resources found abundantly in the Himalayan region (Xu et al., 2009). This natural resource is employed for driving Gharat and used in processing of food grains by the inhabitants in remote villages throughout the Himalayas. Around 2,00,000 watermills have been reported in the Indian Himalayan region which still rely on an ancient design of an impulse-type turbine (Anonymous, 2001; Sharma et al., 2008). The watermill is known by different names like 'Chuskor' in Arunachal Pradesh, 'Rantak' in Ladakh, 'Gharat or ghat' in Uttarakhand but most popularly known as Gharat in the entire Indian Himalayan region (Behari \& Bhardwaj, 2014; Slathia et al., 2018). Today traditional watermills have survived on a small-scale in rural regions of the world like the Himalayas, which are serving mountain inhabitants till date (Vashisht, 2012). This simple technology is still a source 
of income for many people in the remote areas that is used to process good quality flour (Sinha et al., 2008).

The state of Himachal Pradesh is one such Himalayan region where around 89.96 percent population lives in remote rural areas. The major occupation of the people is agriculture and the major crops cultivated are wheat and maize (ENVIS, 2011). Being a hilly terrain, the state has a number of perennial water sources that are functional throughout the year and people of the region use 'Gharat' for processing food grains. Therefore, the present study was undertaken in Chamba region of Himachal Pradesh with the following objectives (1) Assess the present status of Gharats in the study areas, (2) Document the number of crops that are processed at the Gharats, (3) Resource use in the construction of Gharat and its working technique and (4) Responses of the informants pertaining to motivational and demotivational factors about Gharat. The present study would be useful in providing corrective measures for the restoration of this dwindling indigenous technology in one hand and securing the livelihood of the inhabitants on the other.

\section{Materials and methods}

\subsection{Study area}

Himachal Pradesh is located in the heart of the western Himalayan region. Chamba is one of the districts in the state between $32^{\circ} 11^{\prime}$ and $33^{\circ} 13^{\prime}$ North latitude and $75^{\circ} 49^{\prime}$ and $77^{\circ}$ $3^{\prime}$ East longitude, with an estimated area of $6522 \mathrm{Km}^{2}$ and altitudinal range from 800 to $5200 \mathrm{~m}$ amsl. The region is bound on north-west by Jammu and Kashmir, on the north-east and east by Ladakh, south-east by Bara-Bhangal area and in the south by district Kangra of Himachal Pradesh and Gurdaspur district of Punjab (Census of India, 2011). The region is rich in floral and faunal diversity. Surveys were conducted in the selected villages of Pangi and Tissa regions. Pangi is an isolated valley that is geographically divided into three major regions, i.e., Saichu, Sural Bhatori and Hudan Bhatori. The Saach Pass is the gateway to this valley located at an altitude of $4400 \mathrm{~m}$. Chandrabhaga river flows through the region and it remains secluded from rest of the district during winters due to heavy snowfall. Two tribal communities Pangwals and Bhots inhabit the area. In the Tissa region, Gujjar tribal population inhabits the area besides other indigenous communities. River Ravi flows through the Tissa region.

\subsection{Data collection}

Field surveys were conducted in the 20 selected villages of the Pangi and Tissa regions (10 each) from the year 2016-2019. Information was collected through field observations and personal interviews with the Gharatis (owners), artisans, elderly informants and inhabitants living in the vicinity of Gharats through a semi-structured questionnaire. Information was collected pertaining to the status of Gharats in the villages [number at present (i.e., 2016-2019) and before 2016], resources used in the construction of the Gharat, its operational technique, parts of the Gharat in the local dialect, crops processed in the Gharat etc. The Gharatis, (owners of the Gharat/s) were specifically interviewed pertaining to various parts of the mill and bioresource use for its construction. A local guide was hired who helped us in easy communication with the people by translating local language into 
Hindi. Prior to the interview process, the informants were made aware of the objective of the study and their consent for participation was taken.

\subsection{Motivational/demotivational factors}

Further informants were asked about the motivational/demotivational factors responsible for the increase or decline in the number of Gharats in the region. These were later classified into various indicators or responses (Table 1). The number of responses that favoured each motivational factor was then evaluated based on percept responses. Based on the responses of the informants on motivational and demotivational factors, we proposed the corrective measures. It is presumed that these will help the policy makers, conservationists and environmentalists to take appropriate decisions while framing policies for the conservation of Gharats in these regions. Data thus collected were entered and analyzed in Microsoft Excel and descriptive tools (averages, frequencies and charts) were applied.

\section{Results}

\subsection{Status of Gharats in the study sites}

A total of 20 villages were surveyed for collecting information from a total of 95 informants from both the selected sites. In the Pangi region, surveys were conducted in the Dharwas, Hudan, Kiryas, Karhoti, Kawas, Kumar, Kuthal, Punto, Sach and Sural villages while in the Tissa region Chanju, Devikothi, Gwari, Jungra, Khushnagri, Salela, Sanwal, Satyas, Shaktinala and Tarela villages were surveyed (Fig. 1). The results showed that in the Pangi region new Gharats have been constructed in some of the villages. Newly built Gharats were found in the villages like Hudan, Karhoti, Kawas (1 no. each), Kumar (5 no.), Kuthal (4 no.) and Punto (3 no.). In some villages of Pangi, a minor decline in the number of Gharats was also observed which were damaged due to natural calamities like cloudburst, avalanches, flood occurring during winter season. In the village Kriyas, a total of 12 Gharats were present before 2016 out of which only 7 were found functional. In village Dharwas out of 6 Gharats, 1 was non-functional while 5 were still operating well and in Sural out of 9 Gharats 3 were non-functional. While a major decline in the number of Gharats in almost all the surveyed villages was found in the Tissa region. In the villages like Devikothi and Satyas, not a single Gharat was found operational while in the Tarela village out of 12 functional Gharats in the past, only 2 were found operational at present. In the Sanwal village where there were about 15 Gharats in the past, presently only 7 Gharats were operational while in Shaktinala village out of 12 functional Gharats in the past only 5 were found operational. In the Changu village where 15 Gharats were functional in the past, only 7 were found functional (Table 2).

\subsection{Commonly grown crops and their significance in the study areas}

The inhabitants of Pangi region follow rich culture and celebrate a number of fairs and festivals throughout the year. During ceremonial occasions, they prepare a number of dishes that are made from the flour of different crops grown in the area. Variety of cereals/pseudo cereals are cultivated and consumed by the Pangwals that include Amaranthus paniculatus, Eleusine coracana, Fagopyrum esculentum, Fagopyrum tataricum, Hordeum vulgare, 


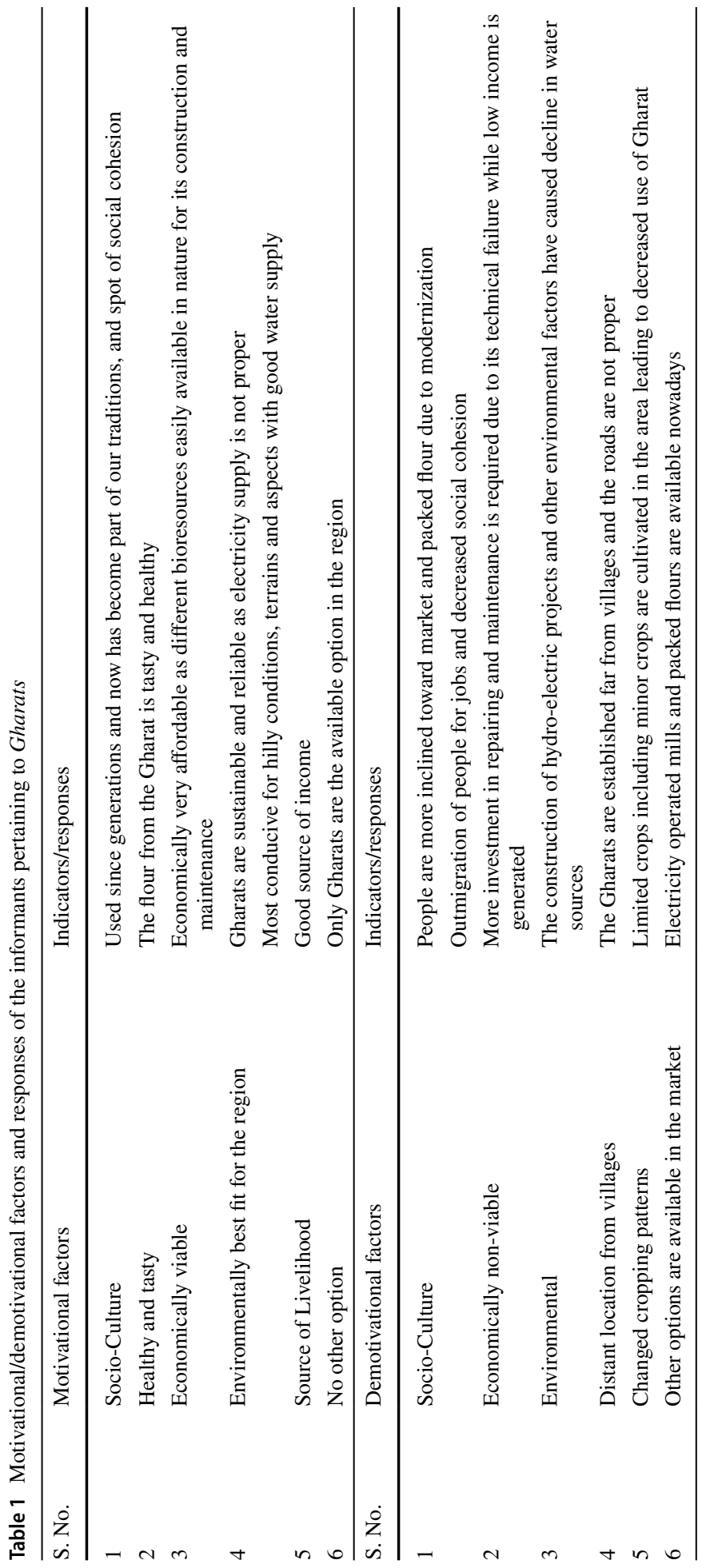




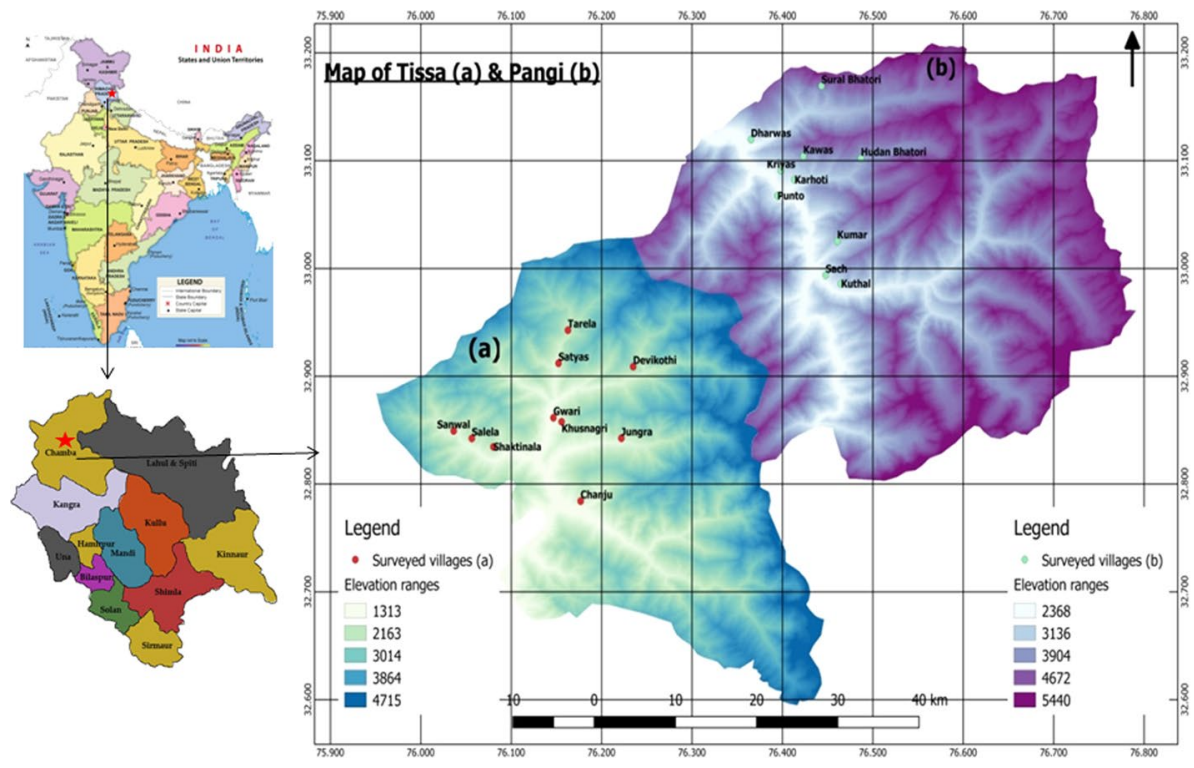

Fig. 1 Map of the study area in India showing (in red and green) the location of surveyed villages

Table 2 Status of number of Gharats (water mills) in the past and present in the study area

\begin{tabular}{llllll}
\hline Name of village & Altitude (m) & $\begin{array}{l}\text { No. of Gharats in the } \\
\text { past (before 2016) }\end{array}$ & \begin{tabular}{l} 
Present number (since 2016) \\
\cline { 3 - 4 }
\end{tabular} & Functional & $\begin{array}{l}\text { Status } \\
\text { (D-decline)/ }\end{array}$ \\
(I- increase)
\end{tabular}

Site 1-Pangi

\begin{tabular}{|c|c|c|c|c|c|}
\hline Dharwas & 2378 & 6 & 5 & 1 & $\mathrm{D}$ \\
\hline Hudan & 3676 & 5 & 6 & 0 & I \\
\hline Karhoti & 2650 & 0 & 1 & 0 & I \\
\hline Kawas & 3622 & 0 & 1 & 0 & I \\
\hline Kriyas & 2870 & 12 & 7 & 5 & $\mathrm{D}$ \\
\hline Kumar & 3051 & 0 & 5 & 0 & I \\
\hline Kuthal & 3303 & 0 & 4 & 0 & I \\
\hline Punto & 2640 & 1 & 3 & 0 & I \\
\hline Sach & 2935 & 1 & 1 & 0 & - \\
\hline Sural & 3347 & 9 & 6 & 3 & $\mathrm{D}$ \\
\hline \multicolumn{6}{|l|}{ Site 2- Tissa } \\
\hline Chanju & 1871 & 15 & 7 & 8 & $\mathrm{D}$ \\
\hline Devikothi & 2524 & 12 & 0 & 12 & $\mathrm{D}$ \\
\hline Gwari & 1378 & 10 & 4 & 6 & $\mathrm{D}$ \\
\hline Jungra & 2100 & 16 & 10 & 6 & $\mathrm{D}$ \\
\hline Khusnagri & 1715 & 17 & 8 & 9 & $\mathrm{D}$ \\
\hline Salela & 1873 & 3 & 1 & 2 & $\mathrm{D}$ \\
\hline Sanwal & 1930 & 15 & 7 & 8 & $\mathrm{D}$ \\
\hline Satyas & 1852 & 20 & 0 & 20 & $\mathrm{D}$ \\
\hline Shaktinala & 2084 & 12 & 5 & 7 & $\mathrm{D}$ \\
\hline Tarela & 2900 & 12 & 2 & 10 & $\mathrm{D}$ \\
\hline
\end{tabular}


Panicum miliaceum, Paspalum scrobiculatum, Triticum aestivum and Zea mays (Table 3). Different types of breads called 'Thothe' and multigrain delicacy called as 'Sattu or Totu' are made from the flours of these crops. Besides this, the Pangwals indigenously process and extract oils from the kernels of Prunus armeniaca and Juglans regia. The kernels after sun-drying are grinded in the watermill to obtain its flour. The flour obtained is mixed with water to make a gruel which is then put on fire. On heating the oil starts to separate and float which is then transferred to another container and is used in day-to-day cooking. During summers, grinding of grains at the Gharats is a busy affair in this region as every household stores the required stock of flour for the whole year. The Gharats become non-functional in the region after the onset of winters (December to May) primarily due to heavy snowfall and freezing of water sources, avalanches and landslides. People in the region frequently use hand operated stone mills to make flour from the kernels at home. Thus, the hand operated stone mills called 'hatath' are of extreme importance and usage during this period (Fig. 2a). In the Tissa region maize and wheat are the major crops grown and the inhabitants use its flour to make chappatis (bread) or halwa (sweet delicacy). The cultivation of other crops like barley and millets has declined in the region over the period of time. The electric flour mill has been installed at many places in the Tissa region (Fig. 2b) and people also procure packed flour from the ration depot.

\subsection{Resource use pattern in the construction of Gharat}

A mill is installed inside a small chamber that is constructed using locally available natural resources, such as stone, mud, wood, bamboo slate and cowdung. The stones are piled one above the other in a regular pattern to form the walls. On the inside, walls and floor are smoothened using mixture of clayey mud and cowdung that is well plastered. On the roofs are placed large logs of wood or bamboo as per the availability of material and then covered with slates, flat stones, sandy soil mixed with dry grass etc.

The whole structure of the mill that consists of various parts is then installed inside this chamber. The installation process is the collaborative work of the local carpenters and blacksmiths. The species of gymnosperm wood (Cedrus deodara, Picea smithiana,

Table 3 Plants grown and processed in the Gharats in the study areas

\begin{tabular}{llllll}
\hline S. No. & Crops & & Part processed & Pangi & Tissa \\
\cline { 2 - 5 } & Scientific name & Local name & & & \\
\hline 1 & Amaranthus paniculatus & Siul/bhavri & Grains & C, P & C \\
2 & Eleusine coracana & Koni & Grains & C, P & - \\
3 & Fagopyrum esculentum & Bhares & Grains & C, P & - \\
4 & Fagopyrum tataricum & Phullan & Grains & C, P & - \\
5 & Hordeum vulgare & Elo & Grains & C, P & C, P \\
6 & Juglans regia & Akhrot & Kernels & C, P & C \\
7 & Panicum miliaceum & Chinay & Grains & C, P & - \\
8 & Paspalum scrobiculatum & Kodra & Grains & C, P & - \\
9 & Prunus armeniaca & Khumani & Kernels & C, P & C \\
10 & Triticum aestivum & Gehun & Grains & C, P & C, P \\
11 & Zea mays & Makki & Grains & C, P & C, P \\
\hline
\end{tabular}

Abbreviations: 'C'=cultivated; 'P' = processed; '-' cultivation abandoned 

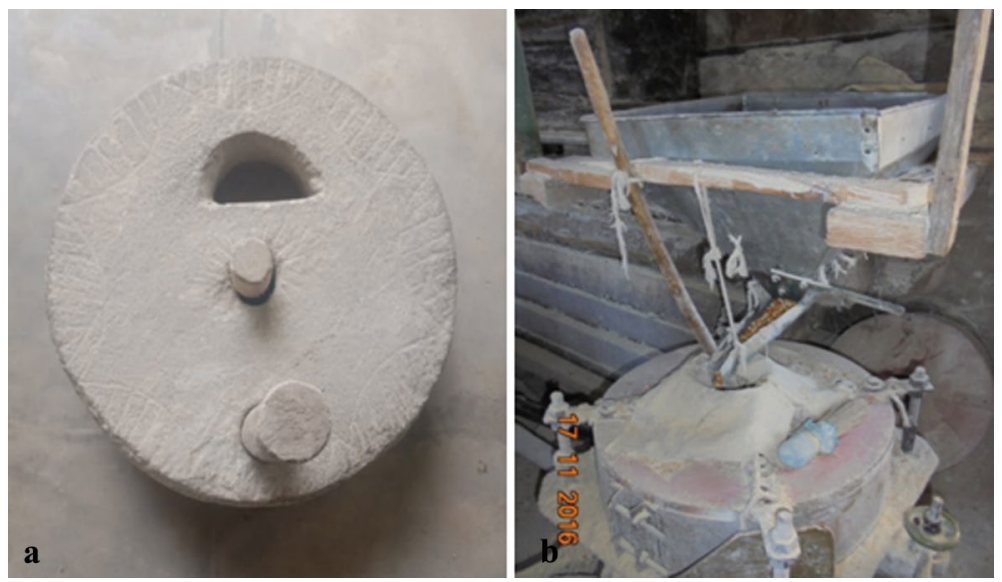

Fig. 2 a Traditional stone hand mill (hatath) in Pangi. b Electric flour mill in Tissa

Pinus roxburghii and Pinus wallichiana) and angiosperm wood (Quercus leucotricophora and Quercus semecarpifolia) are used to make the various parts. The local craftsman (3-4 people) sculpts the granite stone into circular shape with the help of iron tools to make mill panels. The turbine locally called as 'garad' is mainly made of walnut wood (Juglans regia) as it is water resistant and does not easily rotten in water. The dusting of floor before initiating and after completing the grinding process is done using a small broom made indigenously from needles of Pinus spp.

\subsection{Parts of Gharat and operational technique}

Panchakis or watermills are often built on the banks of the Sadanira (perennial sources of water) at a lower height from the water source. The water from the source is diverted through a water channel locally called as 'gool' that is wide from the origin while it narrows toward the turbine to attain a strong flow. A wooden filter is placed in between to prevent the entry of unwanted materials like rocks, twigs etc. that can otherwise obstruct or break the wooden turbine. From gool, the water flows over the wooden/metallic plank connecting from main source till the turbine. Two mill panels (puddle and talli) that are made of stone are placed inside the compartment such that it simultaneously shares an edge with the wheels of the turbine that is placed at the lower end externally. The lower steering wheel is heavy and stable while the upper one revolves with the help of shaft connected with the turbine. The grains are added in a conical-shaped wooden container (daal). The grains of cereal constantly fall in between the puddle (grinding stone) and talli (lower stone) with the vibrations are produced by the grain releasing regulator (reedak). The leveller (kusa) controls the texture of the flour (fine to coarse) and also acts as balance between the puddle and the talli. The pressure of water makes the wings of the turbine (garad) to rotate intensely and thus the whole system operates (Fig. 3). The intensity of flow of water determines the speed of the turbine on which depends the grinding speed of the puddle. On an average if water availability is good then upto $5-10 \mathrm{~kg}$ of flour is produced per hour by a Gharat. 


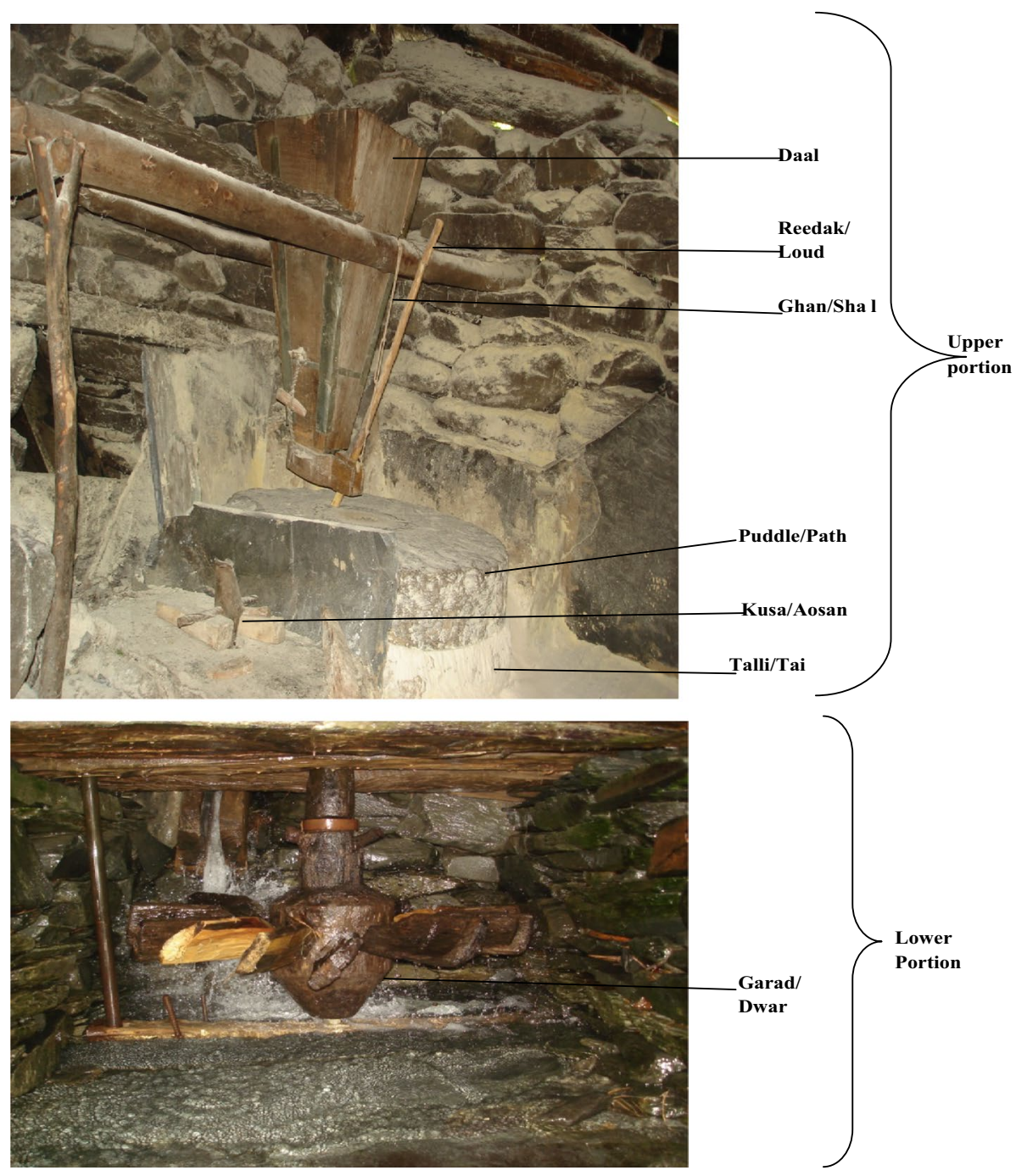

Fig. 3 Pictorial representation of traditional flour mill (Gharat) and its parts in local language

\subsection{Motivational factors about Gharat as per the informants}

On the basis of interviews conducted, the informants including the Gharatis revealed many motivational factors which highlight the benefits of Gharats to these people. Maximum motivational responses were obtained in the Pangi region with large number of responses coinciding for environmentally best fit for the region (47 responses), absence of other options (45 responses), socio-culture (43 responses) and source of livelihood (42 responses). In the Tissa region, the informants gave maximum responses for source of livelihood ( 27 responses) followed by non-availability of other options ( 23 responses) 
and economical (15 responses) (Fig. 4). The various categories of responses have been discussed elaborately.

\subsubsection{Social significance}

People of the region believed that Gharat has a social significance that adds to its popularity and importance for rural population. The people considered the place as a spot of interaction and exchange of information among the people living in nearby villages which added social cohesion among people. By the time, grinding process continued the women folk carried out activities of spinning and knitting of woollen garments. The men were engaged in making ropes and cordage from the fibres obtained from the stem of bamboos, Grewia optiva, Cannabis sativa and Girardinia diversifolia in the Gharats.

\subsubsection{Better taste of the flour}

Maximum informants of higher age group believed that flour from the Gharat was of better quality and taste than the packaged flour brought from the market or the one grinded through electric mill. The people considered the flour nutritious and delicious. In the Pangi region, maximum informants revealed that they had only eaten the Gharat obtained flour since childhood and had never tasted the packaged flour.

\subsubsection{Economically viable}

The informants in both the study sites believed that Gharat is a simple indigenous technology that is environment friendly made from available local resources that makes it cost effective.

\subsubsection{Environmentally best fit for the region}

Due to difficult terrain, tough weather conditions and irregular supply of electricity in these high altitude areas, the inhabitants of the region believed that Gharats were the most suitable option to meet the needs of people.

Fig. 4 Distribution of responses for the motivational factors for Gharat

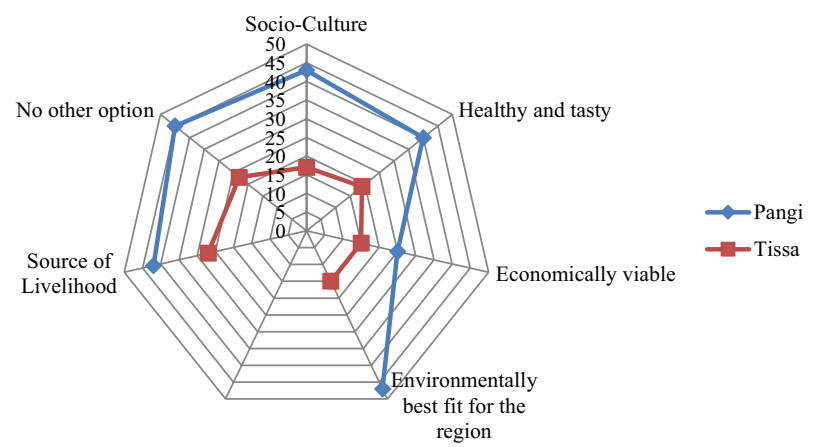




\subsubsection{Source of sustenance and livelihood:}

These are a source of sustenance and livelihood for many inhabitants in the area. The Gharat owners besides operating Gharat were also engaged in other activities like agriculture, livestock rearing, weaving and spinning etc. The Gharati's generally took one tenth of the grains or money in return for the grinding activity.

\subsubsection{Only available option for the inhabitants}

Most of the informants especially from Pangi believed that they are solely dependent on Gharats for grinding grains or used stone querns as no other option is available for them.

\subsubsection{Success story from the area}

During an interview with an elderly informant named Mr. Balku Ram basically a farmer from village Dikriund in Tissa region, a success story was being documented. The person has constructed a self-owned Gharat on the hill top which is operated by releasing water from a cemented tank built at higher elevation from the Gharat (Fig. 5 a, b). The water in the tank regularly gets filled through water supply from the IPH department and rain water. As the water is released from the outlet, the Gharat is operated to grind maize and wheat grains to obtain its flour and on the other side the discharged water from the turbine is directed to irrigate the apple orchard of this farmer (Fig. 5 c, d). This can be considered as the best technique for optimum utilization of water resources as well conservation of the indigenous technology- 'the Gharat'.
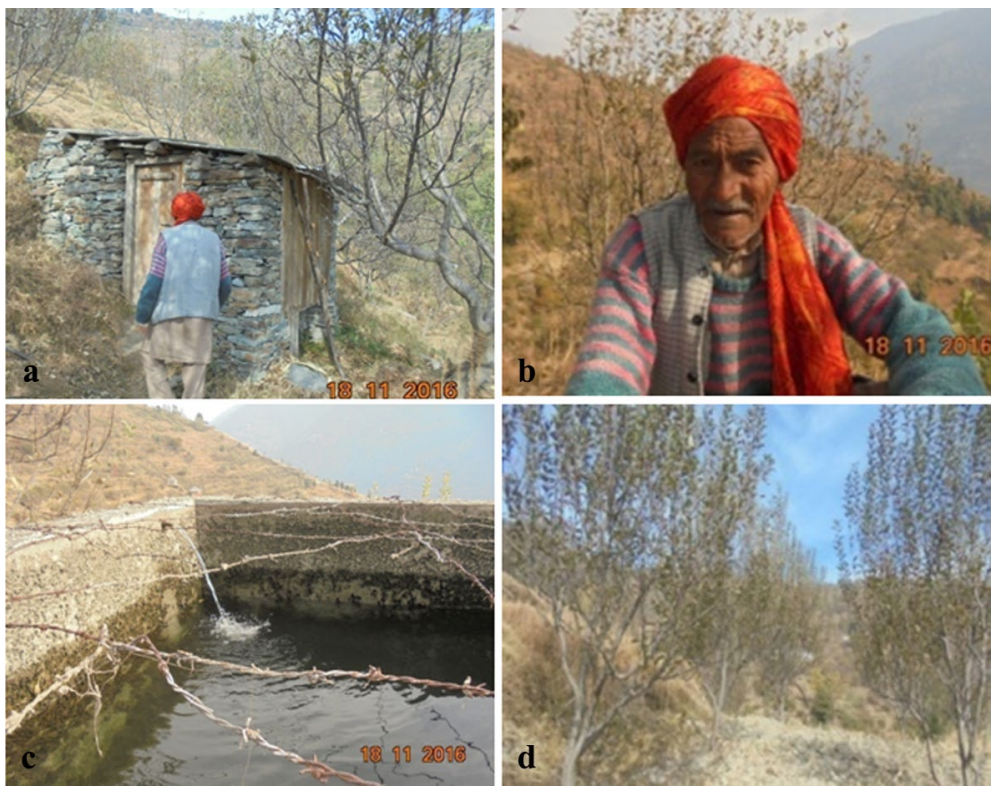

Fig. 5 a Indigenously built 'Gharat' on a hill top. b Local builder Mr. Balku Ram. c Cemented tank built on the hill top for water storage. d Apple orchard of the informant 


\subsection{Demotivational factors about Gharat as per the informants}

There are number of reasons responsible for the abandonment of the watermills that were documented in the present study. Maximum responses under demotivational category were obtained in the Tissa region. Highest responses were obtained for declining water sources (38 responses) followed by economically non-viable (37) responses and lack of sociocultural cohesion (35 responses) (Fig. 6). In the Pangi region, informants gave maximum demotivational responses for distant location of Gharats (10 responses) followed by changing cropping patterns and other options available in the market (7 responses each).

\subsubsection{Socio-culture}

In Pangi region, social cohesion among people is tremendously observed as they celebrate number of fairs, festivals and ceremonies that keep them connected. The perspective of the people is changing in the Tissa region as people are becoming less social and more confined. This may be attributed to increased modernization and out-migration of the people from the villages to cities causing decrease in the rural population.

\subsubsection{Economic-viability}

People are more inclined toward other occupations due to low income obtained from the Gharat that make it a less popular profession. Declining interests of the younger generation toward the age old occupation of water milling due to modernization is also another factor responsible for the decline.

\subsubsection{Geographical and environment issues}

Distant location of Gharats from the habitation sites causes people inconvenience to reach in the absence of proper roads. Various environmental issues like low precipitation, decline in the number of water sources, flash floods and sliding glaciers are other issues.

\subsubsection{Declining water sources}

The various developmental activities like construction of building, roads and hydroelectric projects have resulted in drastic reduction in the number of Gharats due to changes in the

Fig. 6 Distribution of responses for the demotivational factors for Gharat

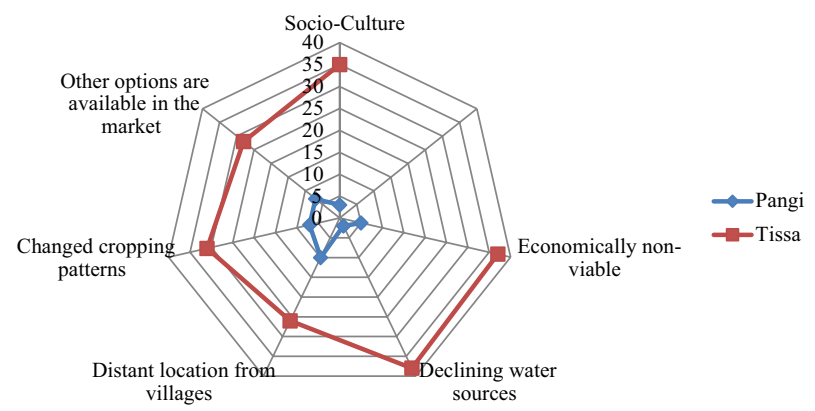


path of water sources in the area. Other environmental issues like lesser rainfall, snowfall etc., and increasing temperature are other causes.

\subsubsection{Distant locations}

The long distances with poor road connectivity of the Gharats from the villages has made Gharats less popular among the inhabitants of the region.

\subsubsection{Changed cropping patterns}

The availability of food grains for grinding has decreased because of changed patterns of crop cultivation and food habits of the people. People are less interested in growing minor food grains and are more dependent on readymade flour from the market or ration depot.

\subsubsection{Other competitors}

The difficult competition to the watermills from the diesel mills has made them less popular among the people in the Tissa region. In the Tissa region, this was more prevalent attribute as compared to the villages of Pangi region. The people of Pangi region in the absence of modern facilities, disrupted electricity supply and abundant water resources in the region consider Gharat as a more reliable source.

\section{Discussion}

Due to scarcity of non-renewable resources of energy and the shortcomings of conventional electrification, the potential of renewable energy sources for energy supply in rural areas is held in high esteem (Haanyika, 2006). Thus, a wide array of renewable energy technologies like biomass, hydel, solar etc. have been harnessed especially for rural areas (Benecke, 2008). At one time, the Gharats were considered as the life line and an integral part of the villagers inhabiting rural mountain areas. Many places of district Chamba, which were accustomed to grinding flour and other foods of antiquity, are witnessing a decline in the number of Gharats at present. This decline in the number of Gharats is at a rapid pace in some villages of Tissa while in the Pangi region the Gharats are still meeting the needs of indigenous people. Many attributes are responsible for the increase or decline in the number. The inhabitants in the far-flung villages of the Pangi region believed that the Gharat was the most viable option due to geographic constraints and also a good source of livelihood as large population is dependent on Gharat for grinding flour in this region. The Pangwals believed that Gharat was a traditional spot of social cohesion. The cultivation of wide varieties of traditional crops that are used by them to prepare different dishes during festivals and ceremonial occasions also keeps the activity of grinding in Gharat intact. The motivational reviews also revealed that the people of the region believed that the flour from the stone grinded mill was of superior quality and taste as compared to the flour obtained from the electric driven mill. Studies conducted in the past have proved that taste, texture, flavour and standard of the flour from the watermill to be far superior to the flour produced through modern mills (Mortiz \& Jones, 1950; Leonard, 1990; Gelinas et al., 2004; Tundup, 2012). As expressed in 'The Bread Book' (Leonard, 1990), the stone-ground flour is 
preferred by many bakers and natural food advocates because of its texture, sweet and nutty flavour, and better baking quality than steel-roller-milled flour.

The reasons for the deterioration of watermills are many but more prominent being the environmental, economical (technological) and socio-cultural factors as documented in the present study (Vashisht, 2012). The construction of various hydro-electric projects have led to changed water courses causing decline in the number of water mills due to which the Gharatis find difficulty in operating Gharats (Sharma \& Rana, 2014; Slariya, 2013; Wilson, 2007). Various developmental activities have caused excessive deforestation and reduced flow of mountain streams (Agarwal, 2006; Vashisht, 2007). The Gharat owners due to low-income, institutional issues and tough competition from electric mills have started abandoning watermills (Paish et al., 1997). The various technological gaps include slower speed, and increased time consumption of the Gharat which needs improvization by simple efforts (Sharma \& Rana, 2014). The channel gradient can be increased, and the turbine as well the grinding stone can be modified quality wise to improve the speed and efficiency of the mill. The wooden parts like the turbine, rotor and shaft can be replaced by the metallic parts to increase the operational efficiency of the Gharat (Pujol et al., 2010, 2015; Shrestha et al., 2014). In the Tissa region, the increased popularity of the electric mills has caused deterioration of the watermills. But it is believed that in due course of time, electric mills run by other resources like kerosene, diesel and petrol etc. that have become popular among the people will prove to be unsustainable in the future (Tsering et al., 2015). The traditional cultural practices are changing and so are the cropping patterns in the Tissa region as people are more inclined toward growing horticulture crops/ cash crops over minor crops in the region (DOA, 2009; Soni et al., 2016).

It is beyond doubt that mountain environment requires appropriate technologies that are locally suited and resilient to environment while sustaining livelihood of the local population. In the present context where the conservation of natural resources is of a great concern, this indigenous technology can prove to be a sustainable means of energy utilization. Mechanical modification in the Gharat can be done for electricity generation by adequate flow of water that can produce at least $5.0 \mathrm{~kW}$ of power at the shaft. This can help in provision of electricity for small number of rural households. This can increase the efficiency of the Gharat that can function even at night by self-electrification and other works like oil extraction, sawing, agro-processing, wool carding, juice extraction etc. can be carried out to enhance the income of the Gharatis (Garg et al., 2015; Hussain \& Hussain, 2014; Sharma et al., 2008; Slathia et al., 2018). Successful modifications of the watermills have been done in the past in various villages of Jammu and Kashmir, Sikkim, Uttarakhand etc. for conservation and sustainable development of traditional knowledge system.

It is essential that government agencies should intervene in the matter and frame policies for skill enhancement, value addition, access to markets and adoption of effective economic and environmental measures to leverage benefits to common people. Maintenance of a GIS database of watermills will enable to track the location of Gharats and help restore the existence of such traditional knowledge that has reached brink of extinction. People's participation is a crucial factor for sustainable development and thus it is important to ensure that these knowledge holding communities are well communicated and their knowledge documented (Jasmine et al., 2016; Roy et al., 1992; Singh \& Sureja, 2006). The indigenous people should be made aware of declining traditional asset- 'the Gharat' by improving its accessibility and visibility for increasing interest among the people. It is essential to learn from the best practices that the indigenous people of the area have developed to survive in the mountain regions (Agarwal, 2006) and make concerted efforts to preserve old traditional knowledge before it is vanished forever (Tsering et al., 2015). 


\section{Conclusion}

Gharats have always been a source of livelihood for people living in remote areas of Himalayan region and an integral part of the cultural heritage. The present study revealed that though the number of Gharats is operating well in the Pangi region, the number has declined considerably in the Tissa region. A number of factors are responsible for the increase or decline in the number from environmental to technological. Therefore, there is an urgent need to revive the watermills to save the indigenous and environment friendly technology being practiced for ages by the indigenous people. At this time of pandemic when the world is battling with covid-19, people have migrated back to their native villages, cities and countries. As per the resolution taken up by the Government of India popularly called as 'Make in India', it is important to find possible indigenous sources of livelihood for the people. It further requires restoring and reviving the dwindling traditional techniques sustainable to Himalayan region and its indigenous people besides taking up other small-scale projects for boosting the economy of the nation. Activities on training, capacity building and subsidy provision by government shall be of immense help for the inhabitants to undertake such projects. Popularization of niche mountain products as highly valuable products and the development of value chains can harness immense benefits to the mountains communities. Thus, a concerted effort is required collectively by the government, institutions and the public to work for the restoration of this historical heritage.

Supplementary Information The online version contains supplementary material available at https://doi. org/10.1007/s10668-021-01455-4.

Acknowledgements The authors are grateful to the knowledge holders among the natives of Pangi and Tissa regions of Chamba district, who shared information freely and without whom this study would not have been possible. Thanks are also due to the government officials deputed in the area for their support during the field studies. We acknowledge the facilities and encouragement provided by the Director, CSIRIHBT, Palampur. We are grateful to DST (Grant No. GAP-0189), Govt. of India for the financial assistance provided under a sponsored project entitled "Network programme on the convergence of traditional knowledge system for sustainable development in the Indian Himalayan Region" and Prof. S.C. Garkoti, JNU for his constant support and cooperation. We thank the Editor and anonymous reviewers for their comments and suggestions.

Author's contribution: AB-Survey, data collection and manuscript writing. DR-Survey, data collection. BL-Conceptualizing the idea, manuscript editing and overall guidance.

\section{References}

Agarwal, S. K. (2006). Re-energizing watermills for multipurpose use and improved rural livelihoods. Mountain Research and Development, 26(2), 104

Anonymous. (2001). Final Report on 'Water Mills'. Prepared by AHEC, IIT Roorkee for UNDP- GEF Hilly Hydro project, MNES, GOI, New Delhi.

Behari, P. C., \& Bhardwaj, A. K. (2014). A case study of improved watermill using power electronics devices for offgrid power generation. Research Journal of Applied Sciences, Engineering and Technology, 7(2), 417-423 
Benecke, G. E. (2008). Success factors for effective implementation of renewable energy options for rural electrification in India- Potentials of the Clean Development Mechanism. International Journal of Energy Research, 32, 1066-1079

Bhatt, A., Rana, D., Uniyal, S. K., Kumar, A., \& Lal, B. (2018). Biodiversity, traditional knowledge and cultural aspects of the native people of Pangi valley, Chamba district, H.P. In Proceedings of international biodiversity congress (IBC, Oct, 2018), Forest Research Institute, Dehradun, India, 4, 1-6.

Boomgaard, P. (2008). Technologies of a trading empire: Dutch introduction of water and windmills in Early-Modern Asia, 1650s-1800. History and Technology, 24(1), 41-59

Census of India. (2011). Himachal Pradesh- district census handbook, Chamba. Retrieved online from http://censusindia.gov.in/2011census/dchb/0201_PART_B_DCHB_CHAMBA.pdfI

DOA. (2009). District Agriculture Plan: Chamba, H.P., Vol.-II.

ENVIS Centre. (2011). Himachal Pradesh status of environment and related issues. Ministry of Environment and Forests, Govt. of India.

Everard, M., Kataria, G., Kumar, S., \& Gupta, N. (2020). Assessing livelihood-ecosystem interdependencies and natural resource governance in a tribally controlled region of India's north-eastern middle Himalayas. Environment, Development and Sustainability,. https://doi.org/10.1007/s10668-020-00945-1

FAO (Food and Agriculture Organization for the United Nations). (2005). State of the World's Forests, Rome.

Garg, A., Agarwal, A., Paredes, L. D., Lentz, M., \& Leiro, A. (2015). Assessing Gharats of the Kamand Valley. Project Report Submitted to IIT.

Gélinas, P., Dessureault, K., \& Beauchemin, R. (2004). Stones adjustment and the quality of stone ground wheat flour. International Journal of Food Science and Technology, 39, 459-463

Haanyika, C. M. (2006). Rural electrification policy and institutional linkages. Energy Policy, 34, 2977-2993

Huddleston, B., Ataman, E., \& d'Ostiani, L. (2003). Towards a GIS- based analysis of mountain environments and populations. Environment and Natural Resources Working Paper No. 10. Food and Agriculture Organization of the United Nations, Rome.

Hussain, A., \& Hussain, N. (2014). Rantak- the traditional watermill of Ladakh, India. Indian Journal of Hill Farming, 27(1), 201

Jasmine, B., Singh, Y., Onial, M., \& Mathur, V. B. (2016). Traditional knowledge systems in India for biodiversity conservation. Indian Journal of Traditional knowledge, 15(2), 304

Körner, K., Ohsawa, M., Spehn, E., Berge, E., Bugmann, H., Groombridge, B., et al., (2005). Mountain Systems: In Hassan, R., Scholes, R., \& Ash, N (eds) Ecosystems and human wellbeing. Current state and trends: Findings of the condition and trends working group. Millennium ecosystem assessment, Vol. 1, Chapter 24, pp. 681-716, Island Press.

Lal, B., Rana, D., \& Bhatt, A. (2019). Natural resource use pattern for self sustenance by the natives of Tissa region of Himachal Pradesh in Western Himalaya, India. In Kumar, S. (ed) Ethnobotany, Vol. 2, Kojo Press, 23 Ansari Road, Daryaganj, New Delhi, pp. 132-152.

Leonard, T. (1990). The bread book. East-West Health Books.

Moritz, L. A. (1958). Grain-Mills and flour in classical antiquity. (pp. 52-67). Clarendon Press.

Mortiz, L. A., \& Jones, C. R. (1950). Experiments in grinding wheat in a Romano- British Quern. Milling, 114,594

Nautiyal, H., Singal, S. K., Goel, V., \& Sharma, A. (2011). Small hydropower for sustainable energy development in India. Renewable and Sustainable Energy Reviews, 15(4), 2021-2027

Paish, O., Armstrong-Evans, R., Saini, R., Singh, D., \& Kedia, D. (1997). The development of traditional himalayan watermills for achieving sustainable village-scale micro-hydropower. First international conference: Renewable energy-small hydropower, Hyderabad, India.

Pereira, T. (2009). Sustainability: An integral engineering design approach. Renewable and Sustainable Energy Reviews, 13(5), 1133-1137

Pérez-Sánchez, M., Sánchez-Romero, F. J., Ramos, H. M., \& López-Jiménez, P. A. (2017). Energy recovery in existing water networks: towards greater sustainability. Water, 9, 97

Pujol, T., Sola, J., Montoro, L., \& Pelegri, M. (2010). Hydraulic performance of an ancient Spanish watermill. Renewable Energy, 35, 387-396

Pujol, T., Vashisht, A. K., Ricart, J., Culubret, D., \& Velayos, J. (2015). Hydraulic efficiency of horizontal waterwheels: Laboratory data and CFD study for upgrading a western himalayan watermill. Renewable Energy, 83, 576-586. https://doi.org/10.1016/j.renene.2015.04.060

Rana, D., Bhatt, A., \& Lal, B. (2020). Studies on lifestyle and livelihood options of the Gujjar Tribe of Tissa Region of District Chamba, Himachal Pradesh in the western Himalaya. In Pant, S., Sharma, A., \& Sharma, V. (eds.) Ethnobotany and biodiversity conservation, Indus Book Services Pvt. Ltd., 21 Ansari Road, Daryaganj, New Delhi, pp. 1-9. 
Rao, K. S. (1997). Natural resource management and development in the Himalaya- a recourse to issues and strategies. Environmental Information system on Himalayan Ecology, G.B. Pant Institute of Himalayan Environment and Development, Almora, India.

Rojas-Sola, J. I., Gómez-Elvira González, A., \& Pérez Martín, E. (2006). Computer-aided design and engineering: A study of windmills in la Mancha (Spain). Renewable Energy, 31, 1471-1482. https://doi. org/10.1016/j.renene.2006.02.002

Roy, S. B., Mukherjee, R. S., \& Chatterjee, M. (1992). Indigenous development in participatory forest management. Journal of Indian Anthropological Society, 27, 48-55

Sánchez-Jiménez, F. J., \& González, J. A. (2018). Watermills: The origin of the use of renewable hydraulic energy in Spain. Industrial Archaeology Review, 40(1), 2-10

Sharma, E., Chattri, N., \& Oli, K. P. (2010). Mountain biodiversity conservation and management: A paradigm shift in policies and practices in the Hindu Kush- Himalayas. International Ecological Research, 25, 909-923

Sharma, H. K., \& Rana, P. K. (2014). Assessing impact of hydroelectric project construction on the rivers of district Chamba of Himachal Pradesh in the Northwest Himalaya, India. International Research Journal of Social Sciences, 3(2), 21

Sharma, R. C., Bisht, Y., Sharma, R., \& Singh, D. (2008). Gharats (watermills): Indigenous device for sustainable development of renewable hydro-energy in Uttarakhand Himalayas. Renewable Energy, 33, 2199-2206. https://doi.org/10.1016/j.renene.2007.12.023

Shrestha, G. R., Kapali, S. P., \& Pakhrin, A. (2014). Case study- Nepal Improved Water Mills. Centre for Rural Technology (CRT/N), Nepal, Kathmandu.

Singh, R. K., \& Sureja, A. K. (2006). Community knowledge and sustainable natural resources management: Learning from the Monpa of Arunachal Pradesh. Journal of Trans-disciplinary Research in Southern Africa, 2(1), 73

Sinha, A. K., Vasishat, R. N., Banerjee, B. G., \& Ghosh, A. (2008). Reinventing the watermill in the Himalaya: The Gharat in history and modern development. Published by Northern Book Center.

Slariya, M. K. (2013). hydroelectric power projects- a threat to existing traditional knowledge: A study of power projects in ravi basin in chamba district of Himachal Pradesh. Asian Journal of Multidimensional Research, 2, 3

Slathia, P. S., Kumar, R., Paul, N., Sharma, B. C., Peshin, R., \& Gupta, S. K. (2018). Traditional water mills (Gharats): A source of livelihood in mountainous regions in Jammu and Kashmir. Indian Journal of Traditional Knowledge, 17(3), 569

Soni, R. P., Pathania, P., \& Katoch, M. (2016). Successful cultivation of cash crops- a step towards diversification in agriculture in Chamba district of Himachal Pradesh. Journal of Agricultural Engineering and Food Technology, 3(2), 125-128

Tsering, G., Nimasow, G., \& Nimaso, O. D. (2015). Chuskor: An indigenous watermill for sustainable resource utilization by the monpa tribes of Arunachal Pradesh, India. Current Science, 109(2), 247

Tundup, T. (2012). Traditional farming system of Ladakh. A radio talk by a local progressive farmer in Dzotang-dzomo programme of All India Radio (AIR), Leh on 22 November 2012.

Vashisht, A. K. (2007). Drought in Uttarakhand, natural or manmade? Current Science, 92(6), 708

Vashisht, A. K. (2012). Current status of the traditional watermills of the Himalayan region and the need of technical improvements for increasing their energy efficiency. Applied Energy, 98, 307

Wilson, A. (2007). The uptake of mechanical technology in the ancient world: the watermill. The Oxford Roman Economy Project. (Accessed online on 17/7/2020).

Xu, J., Grumbine, R. E., Shrestha, A., Eriksson, M., Yang, X., Wang, Y. U. N., \& Wilkes, A. (2009). The melting Himalayas; cascading effects of climate change on water, biodiversity, and livelihoods. Conservation Biology, 23(3), 520-530

Publisher's Note Springer Nature remains neutral with regard to jurisdictional claims in published maps and institutional affiliations. 